Araştırma Makalesi / Research Article

\title{
COVID-19 FARKINDALIK ÖLÇEĞİ (COVFÖ) GELIŞTIRME ÇALIŞMASI
}

\author{
Tuba BÜYÜKBEŞE* \\ Tuğba DİKBAŞ**
}

\section{COVID-19 AWARENESS SCALE (COVFÖ) DEVELOPMENT STUDY}

Öz

$\mathrm{Bu}$ çalışmada, üniversite öğrencilerinin COVID-19 salgınında maske, mesafe, hijyen kurallarına ilişkin farkındalıklarını ölçmek için "COVID-19 Farkındalık Ölçeğì" (COVFÖ) geliştirmek amaçlanmıştır. Pandemi sürecinde COVID-19 virüsünden korunmak için alınan maske, mesafe, hijyen kurallarına özellikle genç nüfusun uymakta zorluk çektiği ya da uymadığı gözlemlenmiş ve ölçme aracına ihtiyaç olduğu belirlenmiştir. Google formda hazırlanan anket sosyal medyada paylaşılarak Türkiye'deki farklı üniversitelerde okuyan üniversite öğrencilerinin ankete katılımı sağlanmıştır. Toplam 1000 üniversite öğrencisinden elde edilen veriler toplandıktan sonra ölçeğin kapsam ve yapı geçerliliği Spps ve Amos programları kullanılarak test edilmiştir. Ölçeğin iç tutarlılık katsayısı .90'dır. Yapılan DFA sonucu ölçek hijyen (12 madde), mesafe (6 madde) ve maske (3 madde) olmak üzere 21 madde ve 3 boyutta doğrulanmıştır. Elde edilen değerler COVFÖ’nün geçerli ve güvenilir bir ölçme aracı olduğunu göstermiştir.

Anahtar Kelimeler: COVID-19, Ölçek, Hijyen, Mesafe, Maske.

\begin{abstract}
This study was aimed to develop the "COVID-19 Awareness Scale" (COVFÖ) to measure the awareness of university students regarding mask, distance and hygiene rules in the COVID-19 epidemic. During the pandemic process, it has been observed that the young population has difficulty or does not comply with
\end{abstract}

* Doç. Dr., Hasan Kalyoncu Üniversitesi, e-posta: tuba.buyukbese@hku.edu.tr, https://orcid.org/0000-0003-4174-9870.

** Bilim Uzmanı, Hasan Kalyoncu Üniversitesi, e-posta: tugbaranadikbas@gmail.com, https://orcid.org/0000-0003-0966-2353.

İntihal Taraması: Bu makale intihal taramasından geçirilmiştir.

Etik Beyan: $\mathrm{Bu}$ çalışmanın hazırlanma sürecinde bilimsel ve etik ilkelere uyulduğu ve yararlanılan tüm çalışmaların kaynakçada belirtildiği beyan olunur (Tuba Büyükbeşe).

Atıf: Büyükbeşe, T. ve Dikbaş, T. (2021), COVID-19 Farkındalık Ölçeği (COVFÖ) Geliştirme Çalışması, 21(2), Abant Sosyal Bilimler Dergisi, s. 21-40, https://doi.org/10.11616/basbed.vi.858037. 
the mask, distance, hygiene rules taken to protect against the COVID-19 virus, and it has been determined that a measuring instrument is needed. The questionnaire prepared with Google form has been shared in social media in order to have participation of students from different universities in Turkey. After collecting the data from a total of 1000 university students, the content and constract validity of the scale was tested using SPSS and Amos programs. The internal consistency coefficient of the scale is .90. According to the result of the CFA, the scale has been verified in 21 items and 3 dimensions as; hygiene (12 items), distance (6 items) and mask ( 3 items). The values obtained have shown that the COVFÖ is a valid and reliable measurement tool.

Keywords: COVID-19, Scale, Hygiene, Distance, Mask.

\section{Giriş}

11 Mart 2020'de COVID-19'un Dünya Sağlık Örgütü (WHO) tarafından küresel salgın ilan edilmesi ve Türkiye'de ilk vakanın görülmeye başlanmasıyla beraber T.C. Sağlık Bakanlığı ve diğer önde gelen sağlık yetkilileri, hızlı yayılan ve insandan insana bulaşan virüsün yayılımının azaltılması ve virüsten korunma yolları olan maske, mesafe ve hijyen koşullarına uygun prosedürler hazırlayıp uygulanması için çalışmalar başlattı. COVID-19 salgınından bireysel olarak korunabilmek için yapılabilecekler şu an çok sınırlıdır. Aşı çalışmaları ülkemizde ve diğer ülkelerde devam etmektedir ve yan etkileri bilinmemektedir. Robert Koch Enstitüsü'nün (RKI, 2020) açıkladığı strateji raporunda COVID-19 aşısı bulunması halinde bile normal hayata dönüşün hızlı bir şekilde mümkün olmayacağına işaret edilmiştir (RKI, 2020; Dw-Almanya, 2020). Prof. Dr. Uğur Şahin, (BioNTech'in CEO'su) The Guardian gazetesine verdiği röportajda aşının asemptomatik vakaları durdurup durdurmayacağının kesin olarak belirlenmesinin bir y1lı bulabileceğini ifade etmiştir (Ntv, 2020). CDC Direktörü Redfield, maske kullanımının son derece önemli olduğuna vurgu yaparak, "Maskenin işe yaradiğına ilişkin çok net bilimsel kanıtlarımız var hatta şunu bile söyleyebilirim maskeler COVID-19'a karşı korunma noktasında aşıdan daha garantili." "Kamu sağlı̆̆ı için maskeler şu an elimizdeki en önemli ve güçlü koruyucudur." ifadelerine yer vermiştir (Hürriyet, 2020). Şu an için bilindik ve en kolay korunma yöntemi maske kullanmak, fiziksel mesafeyi korumak ve hijyen kurallarını uymaktır. Ancak bu üç kurala yeterince uyulmamasının da etkisiyle vaka sayılarında ciddi artışlara neden olduğu; ülkemizde T.C. Sağlık Bakanlığı, 24 Kasım 2020 tarihinde 7.381 vaka, 4.543 ağır hasta sayısı, 2 Aralık 2020 tarihinde 6.690 vaka, 5.502 ağır hasta sayısı, 4 Aralık 2020 tarihinde 6.903 vaka, 5.703 ağır hasta, 31 Aralık 2020 itibariyle toplam 20.881 vefat eden kişi sayısı ile (Sağlık Bakanlığı, günlük-genel-koronavirus-tablosu, 2020) kayıtlara geçti. Ulusal ve uluslararası medyadaki haberlerde ve yapılan 
gözlemler sonucu özellikle gençlerin maske, mesafe ve hijyen konularında daha esnek davrandığ 1 ve kurallara uymadığı belirtilmektedir (AA, 2020; DHA, 2020; DW-Almanya, 2020; Hürriyet, 2020; Hürriyet, 2020; Ntv, 2020; Sabah, 2020). Bu nedenle 3.353.456 örgün eğitim gören ön lisans ve lisans üniversite öğrencisinin bulunduğu Türkiye'de (YÖK-istatistik, 2020) virüsün bulaşmasını önlemeye katkı sağlamak amacıyla COVFÖ geliştirilerek üniversite öğrencilerinin maske, mesafe ve hijyen kurallarına ilişkin farkındalığının belirlenmesi amaçlanmıştır.

Pandemiyle mücadelede salgının başından bugüne kadar hazırlanan prosedürlerde, rehberlerde (WHO, 2020; UNISEF, 2020; CDC, 2020) bilimsel araştırmalarda ve deneysel çalışmalarda (Chen, vd., 2020; Shneider, Kudriavtsev Vakhrusheva, 2020); virüsün yayılımının artış gösterdiği kalabalık ortamların hastaneler, okullar, Avm, işyerleri, kamusal alanlar, toplu taşımanın kullanımının en aza indirilmesi; 2 metre fiziksel mesafenin korunması (Xie, Liang, Dulebenets, Mei, 2020); önerilen maske türlerinin kullanılması, ağız ve burnu kapatacak şekilde takılması, gerekli durumlarda koruyucu ekipman kullanması siperlik, gözlük, gibi (Chung, Ling, Seto, Ang, Tambyah, 2014; Howard, vd.,2020; Keeffe, 2020; Knotek, vd.,2020); el hijyeninde s1k s1k elleri y1kamak veya dezenfekte ederek bireylerin kendilerini ve diğer insanları virüsten korumanın önemli olduğunu vurgulamıştır (G. Dominika, S. Dominika, G. Dominika, 2020; Modi, vd., 2020; WHO, Hand hygiene, 2020). WHO'ya (2020) göre, COVID-19 virüsü burun veya ağıdan küçük damlacıklar aracılığıyla kişiden kişiye yayılmaktadır; öksürmek, hapşırmak maske kullanmadan konuşmak veya bulaşmış bir kişiden soludukları takdirde COVID-19'a yakalanma riskleri yüksektir (Howard, vd., 2020; Rahimi ve Abadi, 2020). COVID-19 küresel salgınında farklı ülkelerde yapılan bilimsel araştırmalarda maske, mesafe ve hijyen kurallarına uyumda demografik özelliklerin farklılık yarattığı (Azlan, Hamzah, Tham, Ayub, Mohamad, (2020); Chaturvedi, Vishwakarma, Nidhi, (2020); sosyal mesafenin ülkeden ülkeye değiştiği (Xie, vd. (2020); hijyen (Dominika, vd., 2020; Modi, vd.,2020), maske (Howard, vd.,2020; Knotek, vd.,2020; Keeffe, 2020; Modi, vd., 2020) ve mesafenin (Xie, vd., 2020) COVID-19'un yayılım hızını azaltmada önemli etkiye sahip olduğu tespit edilmiştir (Azlan, vd., 2020; Bozkurt, 2020; Chaturvedi, vd., 2020; Dominika vd., 2020; Howard, vd.,2020; 2020; Keeffe, 2020; Knotek, vd.; Modi, vd., 2020; Xie, vd., 2020). Bu nedenle, hükümetler ve sağlık bakanlıklıkları fiziksel mesafeyi korumanın COVID-19 salgınında önemli rolü olduğunu vurgulamaktadir (Leung, Migliori, Cheng, 2020; Olagunju, Bolarinwa, Babalola, 2020). RKI ise 2020 y1lı strateji raporunda yeni vakaların ortaya çıkmaması ve pandemiyle mücadelede eğitim kurum ve kuruluşların ekonomik ve toplumsal olarak, COVID-19 salgının uzun vadeli etkilerinin 
azaltılması ve vefatların engellenmesi için alınacak tedbirler arasında sağlık sisteminin de yükünün azaltılmasına dikkat çekerek mesafenin korunması, hijyen önlemleri, maske ve havalandırma tedbirleriyle kurallarına uyulmasının önemli olduğunun altını çizmektedir (DwAlmanya, 2020).

COVID-19 salgını sürecinde eğitim kuruluşları ve üniversiteler, pandemiden en çok etkilenen sektörlerden olmuştur. Mart ayından itibaren üniversitelerin birçoğunda çevrim içi eğitime geçilmiştir. Virüsün ilk dalgası Mayıs-Haziran 2020'ye kadar devam etmiştir. Bazı ülkeler okulları ve üniversiteleri yeniden açarak önerilen kısıtlamaları gevşetmiştir ancak virüsün ikinci dalgasıyla Temmuz- Ekim 2020'ye kadar devam etmesi ve virüsün yayılım göstermesi ile birlikte okulları tekrar kapatmak zorunda kalmışlardır. Virüsün artış göstermesine bağlı olarak UNESCO- UNICEFWorld Bank (2020) koordineli olarak ülkelerde okulların kapanması ile ilgili olarak 1.Tur (Nisan-Haziran), 2. Tur (Temmuz-Ekim) araştırma anketi başlatmıştır ve raporlamıştır. Araştırmaya katılan ülkelerin çoğu, henüz okulların hangi tarihte açılması konusunda karar vermiş değildir. Üniversitelerin kapanması ile birlikte eğitimin devamının sağlanması hükümetlerin önceliği haline gelmiştir. Yükseköğretim Kurulu (YÖK, 2020) ve T.C. Sağlık Bakanlı̆̆ı'nın (2020) aldığı karar ve yayımladıkları rehberle, pandemiyle mücadelede virüsün akademisyen ve öğrencilere bulaşmasını önlemek için ve bilgi kaybı yaşanmaması adına yüz yüze eğitimden, çevrim içi eğitime geçiş yapmıştır (YÖKAK, 2020; Erkut, 2020; WHO-online, 2020; Vigdor ve Ladd, 2010). Bu süreç içinde, üniversite öğrencilerinin yeni yaşam kurallarına (maske, mesafe, hijyen) uyumları ve eğitimin aksamaması için çevrim içi eğitim platformlarına uyum sağlayarak yüz yüze eğitimde olduğu gibi, derslerin devamını sağlamaları amaçlanmıştır (OECD, 2020a, 2020b, 2020).

Ülkemizde üniversite öğrencilerinin COVID-19 farkındalığını ölçen bir ölçeğe rastlanmamıştır. Bu yönüyle geliştirilen ölçeğin literatüre ve bu konuda çalışanlara katkı sağlayacağı düşünülmektedir.

\section{Yöntem}

\subsection{Evren ve Örneklem}

Araştırmanın evrenini, Türkiye'de örgün öğrenim görmekte olan lisans ve ön lisans düzeyindeki öğrenciler oluşturmaktadır. Kolayda örnekleme yöntemi tercih edilmiştir. Örneklem grubuna internet üzerinden twitter, linkedin, 1nstagram, whatsApp gibi çevrim içi iletişim araçları ile ulaşılmış, 1000 öğrenci Google formla hazırlanmış olan ankete katılım sağlamıştır. Bu öğrencilerin 707'si (\%70,7) kadın, 293'ü (\%29,3) erkektir. 
Yaş dağılımına bakıldığında \%31,6'sı 18-20 yaş, \% 57,0’ı 21-25 yaş, \%7,9'u 26-30 yaş, \%3,5'i 31-35 yaş aralığındadır. Medeni durum dağılımına bakıldığında öğrencilerin 42'si (\%4,2) evli, 958'si $(\% 95,8)$ bekardır. Öğrencilerden okudukları bölümü manuel olarak girmeleri istenmiştir, bölüm dağılımlarına göre: Sağlık, Sosyal, Fen, Eğitim bilimleri ile ilgili bölümlere ayrılmıştır. Buna göre sağlık bölümlerinden 227 (\%22,7), sosyal bölümlerinden 200 (\%20), fen bölümlerinden 424 (\%42,4 ), eğitim bölümlerinden $149(\% 14,9)$ öğrenci ankete katılım sağlamıştır.

\subsection{Veri Toplanması ve Analizi}

Araştırmanın yapılması için Hasan Kalyoncu Üniversitesi Etik Komisyonunun 16 Aralı 2020 tarihli toplantısında E--804.012012160011 sayılı etik kurul onayı alınmıştır. Araştırmada üniversite öğrencilerinin COVID-19 salgınında maske-mesafe-hijyen konusundaki farkındalıklarını tespit etmek amacıyla "COVID-19 Farkındalık Ölçeği" (COVFÖ) kullanılmıştır. COVFÖ geliştirme sürecinde Cronbach (1984), De Vaus (2002) ve Crocker ve Algina (1986) tarafından önerilen aşamalar göz önünde bulundurulmuştur. Ölçeğin geliştirilme sürecinde takip edilen aşamalar şöyledir.

\section{3. Ölçülmek İstenen Yapının Açıkça Belirlenmesi}

$\mathrm{Bu}$ araştırmada geliştirilmesi ve denenmesi tasarlanan COVID-19 Farkındalık Ölçeği (COVFÖ) aracılığıyla üniversite öğrencilerinin maske, mesafe ve hijyen konusundaki algı ve farkındalıklarının ölçülmesi hedeflenmiştir.

\section{4. Ölçülecek Yapının Maddelerinin Oluşturulması}

COVFÖ geliştirilirken pilot çalışma kapsamında 20 üniversite öğrencisiyle ön görüşmeler yapılarak nitel veriler toplanmıştır. Nitel veriler hibrit eğitime geçen öğrencilerden gözlem ve görüşme yöntemi ile toplanmış olup, ögrencilerin sosyal mesafe kurallarına ne kadar dikkat ettikleri, maske kullanıp kullanmadıkları, maske kullanım süreleri, ne tür maske kullandıkları ellerini ne sıklıkta, ne ile ne zaman yıkadıkları, toplu taşıma kullanıp kullanmadıkları yanıt aranan sorulardan birkaçıdır. Yerli ve yabancı literatür taranarak maske, mesafe ve hijyenle ilgili araştırmalar incelenmiş; Bozkurt (2020)'un Covid-19'un etkilerini 5338 kişi üzerinde araştırdığı çalışma, Modi, vd. (2020)'nin sağlık lisans öğrencileri ve sağlık personelinin maske, mesafe ve hijyen kullanımını araştırdığı çalışma, Dominika, vd. (2020)'nin COVID-19 salgınının Polanyalı öğrencilerin el hijyeni davranışları üzerine, Xie, vd. (2020)'nin Çin'de sosyal mesafe algısı üzerine yapılan araştırma ve WHO (Survey ToolAnd Guidance 
2020) Anket Arac1 ve Rehberinde yer alan COVID-19 ile maske, mesafe ve hijyenle ilgili soru/ifadelerden faydalanılmıştır.

Nitel verilerin analizi ve ilgili çalışmalardan (Bozkurt, 2020; Dominika, vd. 2020; Modi, vd. 2020; WHO(Survey Tool And Guidance) 2020; Xie vd. 2020) elde edilen bulgular neticesinde ortaya çıkan temalar maske, mesafe ve hijyendir.

\subsection{Madde Havuzunun Oluşturulması}

COVFÖ maddelerinin yazımında nitel verilerden elde edilen temalar ile Bozkurt, 2020; Dominika, vd. 2020; Modi, vd. 2020; WHO (Survey Tool And Guidance) 2020; Xie vd. 2020'nin çalışmaları dikkate alınmıştır. Madde havuzu oluşturulurken üç boyut için toplamda 43 maddelik bir madde havuzu oluşturulmuştur. Ölçek kesinlikle katılmıyorum önermesinden, kesinlikle katılıyorum önermesine doğru uzanan beşli likert türünde hazırlanmıştır.

\subsection{Madde Havuzunun Uzman Görüşüne Sunulması}

Madde havuzunda bulunan maddeler iki alan ölçme-değerlendirme ve iki dil uzmanının görüşlerine sunularak maddeleri anlamsal belirginlik, görünüş geçerliği, kapsam geçerliği ve dilbilgisi bakımından incelemeleri sağlanmıştır. Maddeler, ölçeği meydana getiren 3 faktör çatısında tasnif edilerek uzmanların fikirleri alınmıştır. Uzmanlardan her bir maddenin bulunduğu faktörü karşılayıp karşılamadığına ilişkin fikir bildirmeleri talep edilmiştir. Uzman görüşleri doğrultusunda bazı maddelerin yazımında değişikliğe gidilmiştir. Ayrıca 8 madde uzman görüşleri doğrultusunda madde havuzundan çıkarılmıştır.

\subsection{Pilot Uygulama}

Asıl örneklemin dişında 47 kişiye ölçek pilot uygulaması yapılmıştır. Pilot uygulamada alfa değeri 0,83 gibi yüksek güvenilirlikte bir değer çıkmıştır. Ayrıca pilot çalışma sonrasında güvenilirlik değerleri düşük çıkan 2 madde ölçekten çıkarılmıştır. Nihai uygulama ölçeğin 33 maddelik en son haliyle (maske: 8 madde, mesafe: 8 madde, hijyen: 17 madde) yapılmıştır.

\subsection{Asıl Ölçeğin Uygulanması}

Ölçek formunda gerekli uyarılar yapılarak ölçekte yanlış ya da doğru yanıtların olmadığı ve işaretlenen her yanıtın büsbütünüyle bireysel inanç ve fikirleri temsil ettiği vurgulanmıştır. Veriler gönüllülük esası dikkate alınarak 16.12.2020 ile 31.12.2020 tarihleri arasında çevrim içi ortamda toplanmıştır. 


\subsection{Bulgular}

\subsubsection{Maddelerin Geçerlik ve Güvenirliğine İlişsin Yapılan İstatistiksel Analizler}

Ölçeğin yapı geçerliği tespit etmek için açımlayıcı faktör analizi (AFA) yapılmıştır. AFA yapılmadan önce verilerin faktör analizine uygunluğunu belirlemek amaciyla Kaiser Meyer Olkin (KMO) örneklem yeterliği katsayısının ve Barlett Küresellik testi manidarlık değeri hesaplanmalıdır. KMO değeri 0,50 'den büyük olması ölçek içerisinde yer alan her bir değişkenin diğer değişkenleri yordayacağı anlamını taşımaktadır (Field, 2013). Bu araştırmada yapılan çözümleme neticesinde KMO örneklem yeterliği katsayısı $(0,935)$ bulunmuş ve Barlett Küresellik testi neticesi de manidar çıkmıştır $(\chi 2=11398,949, s d=561 ; \mathrm{p}<0,01)$. Bu veriler ölçeğin faktör analizi için uygunluğu şeklinde yorumlanmıştır.

Tekrarlayan AFA analizleri neticesinde maske alt boyutundan dört madde, mesafe alt boyutundan dört madde ve hijyen boyutundan üç madde; birden fazla boyutta yüksek faktör katsayısına sahip olma (binişiklik), düşük faktör katsayısına sahip olma $(0,32$ 'den az) ve herhangi bir boyutta yer almama gibi nedenlerden dolayı ölçekten çıkarılmıştır. Kalan maddelerle yapılan AFA neticesinde ulaşılan faktörler Şekil 1'de gösterilmiştir.

Şekil 1: COVFÖ’nün Faktör Sayısına Yönelik Yamaç Birikinti Grafiği

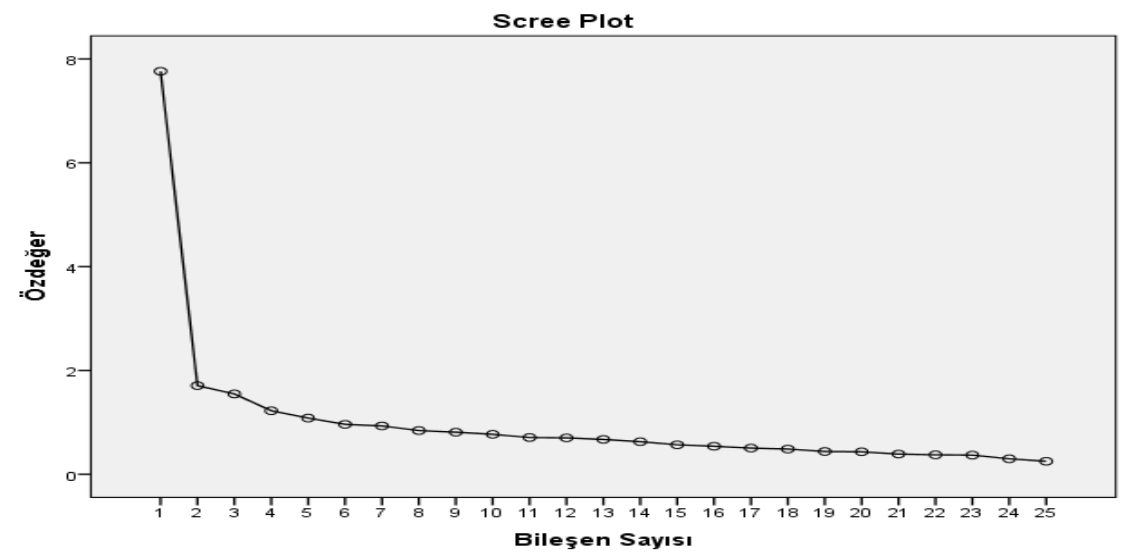

Yamaç-birikinti grafiği incelendiğinde COVFÖ'nün üç boyuttan meydana geldiği görülmüştür. Field'e (2013) ve De Vaus'a (2002) göre grafikteki hızlı ve ani düşüşler boyut sayısını işaret etmektedir. AFA sonucunda elde edilen boyutların varyansları ve özdeğerleri Tablo 1'de gösterilmiştir. 
Tablo 1: COVFÖ’nün Faktör Yapıs1

\begin{tabular}{|c|c|c|c|c|}
\hline $\begin{array}{c}\text { Faktör } \\
\text { Sirası }\end{array}$ & Faktörler & Faktör Özdeğeri & i $\begin{array}{c}\text { Varyans Yüzdesi } \\
(\%)\end{array}$ & $\begin{array}{c}\text { Toplam Varyans Yüzdesi } \\
(\%)\end{array}$ \\
\hline 1 & Hijyen & 4,825 & 19,302 & 19,302 \\
\hline 2 & Mesafe & 3,737 & 14,949 & 34,251 \\
\hline 5 & Maske & 2,456 & 9,822 & 44,074 \\
\hline
\end{tabular}

Tablo 1 incelendiğinde üç faktörden oluşan COVFÖ'nün toplam varyansın \%44,07'sini açıkladığı görülmektedir. Kline'e (2011) göre birden fazla boyuttan meydana gelen ölçeklerde açıklanan toplam varyansın \%41'in üstünde olması yeterlidir. Toplam açıklanan varyansın \%19,30'unu hijyen boyutu, \%14,94'ünü mesafe boyutu ve \%9,82'sini maske boyutu oluşturmaktadır.

Ölçeğin güvenilirlik hesaplaması için her bir alt boyutta yer alan maddeler için güvenilirlik hesaplaması yapılmıştır. Bu noktadan hareketle hijyen boyutunda yer alan iki madde, mesafe boyutunda yer alan bir madde ve maske boyutunda yer alan bir madde alfa katsayıları düşük $(0,32$ 'den az) çıkması nedeniyle veri setinden çıkarılmışlardır. Elde kalan toplam 21 maddeye tekrardan yapılan güvenilirlik analizleri sonucu ölçeğin tamamının alfa katsayısı 0,90 bulunmuştur. Bu değer ölçeğin oldukça yüksek düzeyde güvenilir olduğu şeklinde yorumlanabilir. Alt faktörlerin güvenilirliklerine yönelik bulgular Tablo 2'de gösterilmiştir.

Tablo 2: COVFÖ’nün Alt Boyutlarının Alfa Güvenilirlik Değerleri

\begin{tabular}{|c|c|c|}
\hline $\begin{array}{l}\text { Boyut } \\
\text { Adı }\end{array}$ & Maddeler & $\begin{array}{c}\text { Alfa } \\
\text { Değeri }\end{array}$ \\
\hline Hijyen & $\begin{array}{l}\text { Kişisel yaşamımda hijyene (günlük duş, el hijyeni, diş fırçalamak, } \\
\text { elbisenin temizliği, ev temizliği vb.) dikkat ederim. } \\
\text { Ellerimi, yemeklerden önce/sonra yıkarım. } \\
\text { Ellerimi, eve döndükten sonra yıkarım. } \\
\text { Ellerimi, toplu taşımayı kullandıktan sonra yıkarım/dezenfekte ederim. } \\
\text { Ellerimi, para/banka kartı kullanımı sonrası yıkarım/dezenfekte } \\
\text { ederim. } \\
\text { Ellerimi, insanlarla temasa geçtikten sonra yıkarım/dezenfekte ederim. } \\
\text { Ellerimi, burun sildikten, hapşırdıktan, öksürdükten sonra yıarım. } \\
\text { Ellerimi, çöplere dokunduktan sonra yıkarım/dezenfekte ederim. } \\
\text { Ellerimi yıkarken sabun kullanırım. } \\
\text { El hijyeni için tercih edilen en etkin yöntem, yaklaşık } 20 \text { saniye elleri } \\
\text { sabunla iyice yıkamaktır. } \\
\text { Dışarı çıktığımda/ bulunduğum ortamdaki yüzeylerin (masalar, sıralar) } \\
\text { ve nesnelerin (telefonlar, klavyeler) dezenfekte edilmiş olmasına } \\
\text { dikkat ederim. } \\
\text { Ellerimi göz, ağız, burun gibi organlardan uzak tutmaya dikkat ederim. }\end{array}$ & 0,85 \\
\hline
\end{tabular}




\begin{tabular}{|c|c|c|}
\hline Mesafe & 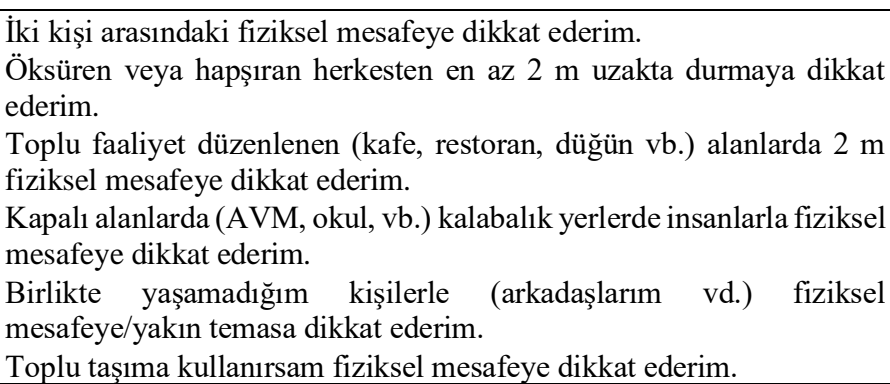 & 0,84 \\
\hline Maske & $\begin{array}{l}\text { Koronavirüsün bulaşmasını önlemek için insanlar maske takmalıdır. } \\
\text { Maske kullanmayanlara cezai işlem uygulanmalı ve zorunlu olmalıdır. } \\
\text { Maske takmanın koronavirüs yayılımının azaltılmasına yardımcı } \\
\text { olduğunu düşünüyorum. }\end{array}$ & 0,73 \\
\hline
\end{tabular}

Tablo 2'de görüleceği üzere COVFÖ’yü oluşturan alt boyutlar oldukça yüksek derecede güvenilir düzeyde çıkmıştır. Madde sayısı 10 ve altında olan ölçeklerde alfa katsayısının 0,60'ın üzerinde olması güvenirlik için yeterli bir ölçüt olarak görülebilir (Field, 2013). Ölçeğin toplam alfa katsayısının 0,90 olduğu dikkate alındığında oldukça yüksek düzeyde güvenilir bir ölçek olduğu yorumu yapılabilir. Bu bulgular doğrultusunda maddelerin boyut yükleri ve boyutlara göre dağılımı Tablo 3 'te gösterilmiştir.

Tablo 3: Alt Boyutlar ve Faktör Yükleri

\begin{tabular}{|c|c|c|c|c|}
\hline Faktör Adı & Madde No. & 1. Boyut & 2. Boyut & 3. Boyut \\
\hline \multirow{12}{*}{ Hijyen } & H7 & 0,722 & & \\
\hline & H6 & 0,719 & & \\
\hline & H5 & 0,695 & & \\
\hline & H9 & 0,677 & & \\
\hline & H10 & 0,648 & & \\
\hline & H11 & 0,618 & & \\
\hline & H14 & 0,554 & & \\
\hline & H15 & 0,518 & & \\
\hline & $\mathrm{H} 2$ & 0,493 & & \\
\hline & H17 & 0,484 & & \\
\hline & H12 & 0,428 & & \\
\hline & H1 & 0,414 & & \\
\hline \multirow{6}{*}{ Mesafe } & MES5 & & 0,790 & \\
\hline & MES6 & & 0,789 & \\
\hline & MES2 & & 0,743 & \\
\hline & MES7 & & 0,688 & \\
\hline & MES4 & & 0,647 & \\
\hline & MES8 & & 0,571 & \\
\hline \multirow{3}{*}{ Maske } & MAS2 & & & 0,832 \\
\hline & MAS8 & & & 0,778 \\
\hline & MAS3 & & & 0,744 \\
\hline
\end{tabular}


Tablo 3 'te görüleceği üzere hijyen faktörünü meydana getiren maddelerin faktör yükleri 0,72 ile 0,41 arasında değişkenlik göstermektedir. Mesafe faktörünü meydana getiren maddeler 0,79 ile 0,57 arasında ve maske faktörünü meydana getiren maddeler ise 0,83 ile 0,74 arasında değişkenlik göstermektedir. Verilerin geçerlik çalışmaları için doğrulayıcı faktör analizi (DFA) uygulanmıştır. DFA modelinin uyumu için karşılaştırmalı uyum indeksi (CFI), düzeltilmiş iyilik uyum indeksi, yaklaşık hataların ortalama karekökü, genel uyum indeksi (GFI), ki-karenin serbestlik derecesine bölümü $(\chi 2 / \mathrm{sd})$ ve artırmalı uyum indeksi (IFI) değerleri kıstas alınmıştır (Çelik ve Yılmaz, 2013; Kline, 2011).

COVFÖ’ye DFA uygulanarak açımlayıcı faktör analizi (AFA) ile elde edilen üç faktörlü yapı test edilmiştir. Ulaşılan DFA sonuçları, AFA ile elde edilen sonuçlarla tutarlı sonuçlar vermiş ve uyum indeksleri mükemmel düzeylerde ç1kmıştır $(\chi 2=571,222, \quad \mathrm{sd}=181, \quad \mathrm{p}<0,01$, $\chi 2 / \mathrm{sd}=3,156, \mathrm{RMSEA}=0,04, \mathrm{GFI}=.95, \mathrm{AGFI}=.93, \mathrm{IFI}=.95, \mathrm{CFI}=.95) . \mathrm{DFA}$ analizi ile kuramsal modelin ulaşılan veriler doğrultusunda yeterliğini belirlemek amacıyla kıstas alınan uyum indekslerine ait değerler ve DFA modeline yönelik uyum değerleri Tablo 4'te gösterilmiştir.

Tablo 4: Kıstas Alınan Uyum İndeksleri* ve Modelin Uyum Değerleri

\begin{tabular}{|l|l|l|l|l|}
\hline & & & \\
& & &
\end{tabular}

*(Çelik ve Yılmaz, 2013; Kline, 2011)

Tablo 4'te görüleceği üzere test edilen teorik modelin veri setiyle uyumlu bir yapıda ve model uyum indeksleri mükemmel düzeydedir. $\chi 2$ değerinin 2 ile 5 arasında olması modelin verilerle kabul edilebilir düzeyde uyumlu olduğunu belirten ilk sonuçtur (Kline, 2011). RMSEA değerinin 0,05' in altında olması modelin verilerle mükemmel düzeyde uyumlu olduğuna 
işarettir. Diğer uyum ölçütlerinin de mükemmel seviyede olması modelin veri setiyle uyumlu olduğunu göstermiştir. Şekil 2'de COVFÖ'ye uygulanan DFA görselleştirilmiştir.

Şekil 2: COVFÖ DFA Sonuçları

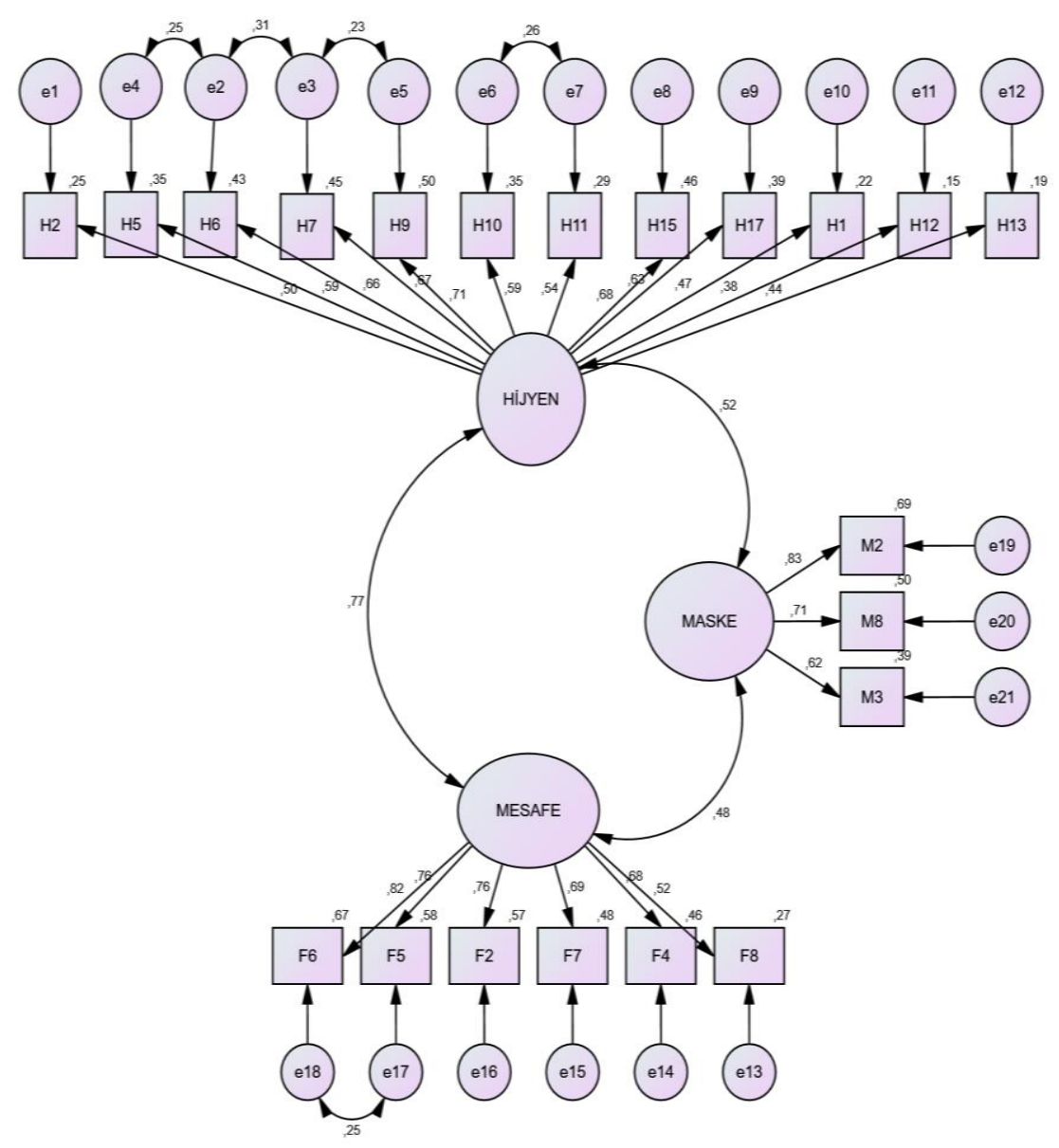


Tablo 5: DFA Sonucu Elde Edilen COVFÖ Faktör Yükleri

\begin{tabular}{|c|c|c|}
\hline Faktör Adı & Madde No. & \\
\hline \multirow{12}{*}{ Hijyen } & $\mathrm{H} 2$ & .50 \\
\hline & $\mathrm{H} 5$ & .59 \\
\hline & H6 & .66 \\
\hline & $\mathrm{H} 7$ & .67 \\
\hline & H9 & .71 \\
\hline & H10 & .59 \\
\hline & H11 & .54 \\
\hline & H15 & .68 \\
\hline & H17 & .63 \\
\hline & $\mathrm{H} 1$ & .47 \\
\hline & H12 & .38 \\
\hline & H13 & .44 \\
\hline \multirow{6}{*}{ Mesafe } & F6 & .67 \\
\hline & F5 & .58 \\
\hline & $\mathrm{F} 2$ & .57 \\
\hline & F7 & .48 \\
\hline & F4 & .46 \\
\hline & F8 & .27 \\
\hline \multirow{3}{*}{ Maske } & M2 & .83 \\
\hline & M8 & .71 \\
\hline & M3 & .62 \\
\hline
\end{tabular}

Ölçekteki maddelere verilen cevaplar: Kesinlikle katılmıyorum 1, kısmen katılmiyorum 2, kararsızım 3, kısmen katıliyorum 4 ve kesinlikle katılıyorum 5 şeklinde puanlanmıştır. Madde aralıklarının yorumlanmasında Tablo 6'da puanlar ölçüt alınmıştır.

Tablo 6: Puanların Yorumlanmasında Kabul Edilen Aralıklar ve Anlamları

\begin{tabular}{|l|l|c|l|}
\hline & İfadeler & $\begin{array}{c}\text { Puan } \\
\text { Aralığı }\end{array}$ & Farkındalık Düzeyi \\
\hline \multirow{2}{*}{$\begin{array}{l}\text { Kesinlikle } \\
\text { katılmıyorum }\end{array}$} & $1,00-1,80$ & $\begin{array}{l}\text { Çok az düzeyde } \\
\text { farkındalık }\end{array}$ \\
\hline FARKINDALIĞI & $\begin{array}{l}\text { Kısmen } \\
\text { katılmıyorum }\end{array}$ & $1,81-2,60$ & Az düzeyde farkındalık \\
\cline { 2 - 4 } & Kararsızım & $2,61-3,40$ & $\begin{array}{l}\text { Orta düzeyde } \\
\text { farkındalık }\end{array}$ \\
\hline & $\begin{array}{l}\text { Kismen } \\
\text { katıllyorum }\end{array}$ & $3,41-4,20$ & $\begin{array}{l}\text { Yüksek düzeyde } \\
\text { farkındalık }\end{array}$ \\
\hline & $\begin{array}{l}\text { Kesinlikle } \\
\text { katıllyorum }\end{array}$ & $4,21-5,00$ & $\begin{array}{l}\text { Cok yüksek düzeyde } \\
\text { farkındalık }\end{array}$ \\
\hline
\end{tabular}


Tablo 6'da görüleceği üzere COVFÖ'den alınan puanlar arttıkça üniversite öğrencilerinin COVID-19 farkındalıkları da artmaktadır.

\section{Sonuç}

$\mathrm{Bu}$ araştırma ile COVID-19 virüsünün hayatımızın gündeminden düşmediği pandemi sürecinde, üniversite öğrencilerinin COVID-19 farkındalıklarını ölçecek geçerli ve güvenilir bir ölçek geliştirmek amaçlanmıştır. Ölçeğin geliştirilmesinde De Vaus (2002) ve Crocker ve Algina (1986) tarafından önerilen aşamalar takip edilmiştir. $\mathrm{Bu}$ aşamalardan ilkinde ölçülmek istenen yap1 (COVID-19 Farkındalığı, maske, mesafe, hijyen) açıkça belirlenmiştir. İkinci aşamada ölçülecek yapıyı karşılayan davranışların açıkça ifade edilmesi; akabinde nitel verilerden elde edilen temalara uygun olarak literatür taraması sonucu oluşturulan 3 boyut ve 43 maddelik havuzunun oluşturulması; sonrasında madde havuzunun uzman görüşüne sunulması ki bu aşamada uzman görüşleri doğrultusunda bazı maddelerin yazımında değişikliğe gidilmiştir. Ayrıca 8 madde uzman görüşleri doğrultusunda madde havuzundan çıkarılmıştır. Ardından pilot uygulama 47 kişiyle gerçekleştirilmiştir. Pilot uygulamada alfa değeri 0,83 bulunmuştur. $\mathrm{Bu}$ aşamada güvenilirlik değerleri düşük çıkan 2 madde ölçekten çıkarılmıştır. Ölçeğin uygulamadan önceki son hali 33 maddedir (maske: 8 madde, mesafe: 8 madde, hijyen: 17 madde). Pilot uygulama sonrası asıl uygulamaya geçilmiştir. Hazırlanan ölçme aracı Google forma yüklenerek sosyal medyada twitter, linkedin, instagram, whatsApp gibi çevrim içi iletişim araçları ile paylaşılmış ve Türkiye' de farklı üniversitelerde öğrenim gören 1000 öğrenci tarafından doldurulmuştur.

Analiz aşamasında ölçeğe önce AFA uygulanmıştır ve COVFÖ’nün toplam varyansın \%44,07'sini açıkladığı belirlenmiştir. Açıklanan toplam varyansın \%19,30'unu hijyen boyutu, \%14,94'ünü mesafe boyutu ve \%9,82'sini maske boyutu oluşturmaktadır. Ölçeğin güvenilirlik analizi sonucu alfa katsayısı .90 bulunmuştur. Bu da ölçeğin yüksek güvenilirliğe sahip olduğunu göstermektedir. Alt boyutlarda ise alfa değerleri maske için 0,73, mesafe için 0,84, hijyen için 0,85 hesaplanmıştır. COVFÖ'nün yapısal geçerliliğini test etmek için AFA ile elde edilen üç boyutlu yapı DFA ile test edilmiş uyum indekslerinin mükemmel düzeyde (biri kabul edilebilir) olduğu görülmüştür. Yapılan araştırmalar ve analizler sonucunda maske, mesafe ve hijyen boyutlarından oluşan 21 maddelik ölçme aracı COVFÖ’nün geçerli ve güvenilir bir ölçme aracı olduğu ve üniversite öğrencilerinin COVID-19 farkındalığını ölçmekte kullanılabileceği sonucuna varılmıştır. Bu ölçek her ne kadar üniversite öğrencileri için geliştirilmiş olsa da yetişkinler için de kullanılabileceği 
düşünülmektedir. Toplumda yetişkinlerin de maske, mesafe ve hijyen konularında çok duyarlı davranmadıklarına tanık olunmaktadır. Bu konuda yetişkinlerin de COVID-19 konusunda daha fazla bilinçlendirilmeye ve farkındalıklarının artırılmasına ihtiyaç duyulmaktadır. COVID-19 hayatımızda olduğu sürece bu konuda farkındalığın ve kurallara (maske, mesafe, hijyen) uymanın kendimizi ve ailemizi korumanın en kolay ve güvenilir yolu olduğu unutulmamalıdır.

\section{Kaynaklar}

Azlan, A.A., Hamzah, M.R., Tham, J.S., Ayub, H.S.,Mohamad, E. (2020), Public knowledge, attitudes and practices towards COVID-19: A cross-sectional study in Malaysia, PLOS ONE 1(15). https://doi.org/10.1371/journal.pone.0233668.

Bozkurt, V. (2020), Pandemi Döneminde Çalışma: Ekonomik Kayglar, Dijitalleşme ve Verimlilik, İstanbul Üniversitesi Yayınevi 2020. https://doi.org/10.26650/B/SS46.2020.005.08.

Can, D. ve Karakuzulu, M. (2020), Maske takmayan gençlerin sözleri şaşırttı. https://www.dha.com.tr/yurt/maske-takmayan-genclerinsozleri-sasirtti/haber-1778239, (Erişim Tarihi: 18.10.2020).

Crocker, L., ve Algina, J. (1986), Introduction to classical and modern test theory, Holt, Rinehart and Winston, 6277 Sea Harbor Drive, Orlando, FL 32887.

Cronbach, L. J. (1984), Essentials of physiological testing, New York: Horner \& Row Publisher.

Chaturvedi, K., Vishwakarma, D.K., Nidhi, (2020), COVID-19 and its impact on education, social life and mental health of students: A Survey, Children and Youth Services Review, S0190-7409 (20) 32288-X. https://doi.org/10.1016/j.childyouth.2020.105866.

Chen, N., Zhou M.,, Dong, X., Qu J., Gong, F., Han, Y., Qiu, Y., Wang, J., Liu, Y., Wei, Y., Xia, J., Yu, T., Zhang, X., Zhang, L. (2020), Epidemiological and clinical characteristics of 99 cases of 2019 novel coronavirus pneumonia in Wuhan, China: a descriptive study, The Lancet, 395(10223). 507-513. https://doi.org/10.1016/S01406736(20)30211-7.

Chung, J.S., Ling, M.L., Seto, W.H., Ang, B.S.P., Tambyah, P.A. (2014), Debate on MERS-CoV respiratory precautions: surgical mask or N95 respirators?, Singapore Medical Journal. 55(6): 294-297. http://dx.doi.org/10.11622/smedj.2014076. 
Çelik, H. E. ve Yılmaz, V. (2013), Yapısal Eşitlik Modellemesi Temel Kavramlar Uygulamalar Programlam, Ankara: Ani Yayıncılık.

Çelik, B. (2020), Toplum Bilim Kurulu'ndan çarpıcı corona virüsü anketi! COVID-19 anketinden çıkan sonuçlar şaşırttı! https://www.sabah.com.tr/yasam/2020/09/26/son-dakika-toplumbilim-kuruluundan-carpici-corona-virusu-anketi-covid-19anketinden-cikan-sonuclar-sasirtti, (Erişim Tarihi: 17.11.2020).

De Vaus, D. (2002), Surveys in Social Research. (5 edition), Australia: Routledge.

Dominika, G., Dominika, S., and Dominika, G. (2020), Population-Based Study of the Influence of the COVID-19 Pandemic on Hand Hygiene Behaviors- Polish Adolescents' COVID-19 Experience (PLACE-19) Study, Sustainability, 12-4930. https://doi.org/10.3390/su12124930.

Erkut, E. (2020), COVID-19 Sonras1 Yükseköğretim. Yükseköğretim Dergisi, 125-133. https://doi.org/10.2399/yod.20.002.

Engür, A. (2020), Corona virüs aşısı olan insanlar maske takmaya devam edecek, https://www.ntv.com.tr/galeri/saglik/corona-virus-asisiolan-insanlar-maske-takmaya-devam-edecek,h-UdCFQCqE-

1Xms5DPMqcQ/pYLz0ctMR0m-14CIg9wACw, (Erişim Tarihi: 28.12.2020).

Field, A. (2013), Discovering Statistics Using IBM SPSS Statistics. (4th Edition). Sage.

Howard, J., Huangb, A., Lik, Z., Tufekcim, Z., Zdimal, V., Westhuizen, H.M., ... Rimoin, A.W. (2020), Face Masks Against COVID-19: An Evidence Review. Preprints (www.preprints.org). 1-9, https://doi.org/10.20944/preprints202004.0203.v1.

Hürriyet, (2020), ABD'nin en yetkin kurumu açıkladı... Ezber bozan maske açıklaması!.https://www.hurriyet.com.tr/galeri-son-dakika-haberiabdli-bilim-insanlari-acikladi-maske-takmak-covid-19-icinbagisiklik-sagliyor-41608115, (Erişim Tarihi: 25.11.2020).

Uzun Bağcı, S. (2020), Salgının belirsizliği huzursuzluğu artırdl. https://www.hurriyet.com.tr/amp/yazarlar/sibel-bagci uzun/salginin-belirsizligi-huzursuzlugu-artirdi-41501744, (Erişim Tarihi: 25.11.2020). 
Keeffe, J.O. (2020), Masking During the COVID-19 Pandemic, National Collaborating Centre for Environmental Health. ISBN: 978-1988234-46-5.

Kline, R. B. (2011), Principles and practice of structural equation modeling (3rd ed.), New York/London: The Guilford Press.

Knotek, E.S., Schoenle, R.S., Dietrich, A.M., Müller, G.J, Kristian, O., Myrseth, R., and Weber, M. (2020), Consumers and COVID-19: Survey Results on Mask-Wearing Behaviors and Beliefs, Economic Commentary is published by the Research Department of the Federal Reserve Bank of Cleveland. 2163-3738 https://doi.org/10.26509/frbc-ec-202020.

Leung, C.C., Migliori, G.B., Cheng, K.K. (2020), Mask wearing to complement social distancing and save lives during Cov1d-19, International Journal Tuberc Lung Dis 24(6):556-558. https://doi.org/10.5588/ijtld.20.0244.

Modi, P.D., Nair, G, Uppe, A., Modi, J., Tuppekar, B., Gharpure, A.S., Langade, D. (2020), COVID-19 Awareness Among Healthcare Students and Professionals in Mumbai Metropolitan Region: A Questionnaire-Based Survey, Cureus 12(4): e7514. https://doi.org/10.7759/cureus.7514.

Nogay, G. (2020), Kovid-19'la maske, sosyal mesafe, hijyen üçlüsüyle mücadele uyarısı, https://www.aa.com.tr/tr/koronavirus/kovid-19lamaske-sosyal-mesafe-ve-hijyen-uclusuyle-mucadele uyarisi/1882626 (Erişim Tarihi: 10.11.2020).

OECD (2020a), A framework to guide an education response to the COVID-19 pandemic of 2020, Paris: OECD Publishing. https://globaled.gse.harvard.edu/files/geii/files/framework_guide_v 1_002.pdf. (Erişim Tarihi: 10.10.2020).

OECD (2020b), Education responses to COVID-19: Embracing digital learning and online collaboration, OECD Policy Responses to Coronavirus (COVID-19). http://www.oecd.org/coronavirus/policy-responses/educationresponses-to-covid-19-embracing-digital-learning-and-onlinecollaboration-d75eb0e8/ (Erişim Tarihi: 15.10.2020).

Olagunju, O.S., Bolarinwa, O.A., Babalola, T. (2020), Social Distancing, Lockdown Obligatory, and Response Satisfaction During COVID19 Pandemic: Perception of Nigerian Social Media Users, Advanced 
Journal of Social Science.7(1).44-53. https://doi.org/10.21467/ajss.7.1.44-53.

Rahimi, F. \& Abadi, B. (2020), Criticality of physical/social distancing, handwashing, respiratory hygiene and face-masking during the COVID-19 pandemic and beyond, International Journal of Clinical Practice 74(11):e13656. https://doi.org/10.1111/ijcp.13656.

Robert Koch

Institut.(2020), https://www.rki.de/EN/Home/homepage_node (Erişim Tarihi: 28.12.2020).

Shneider, A., Kudriavtsev, A., Vakhrusheva, A. (2020), Can melatonin reduce the severity of COVID-19 pandemic?, Internatıonal Reviews Of Immunology. https://doi.org/10.1080/08830185.2020.1756284.

T.C. Sağlık Bakanlığı. (2020), COVID-19 (SARS-CoV-2 Enfeksiyonu) rehberi, https://covid19bilgi.saglik.gov.tr/depo/rehberler/COVID19_Rehberi.pdf. (Erişim Tarihi: 02.10.2020).

T.C. Sağlık Bakanlığı. (2020), https://covid19.saglik.gov.tr/TR66935/genel-koronavirus-tablosu.html (Erişim Tarihi: 30.12.2020).

T.C. Sağlık Bakanlığı. (2020), https://covid19.saglik.gov.tr/TR68443/covid-19-durum-raporu.html (Erişim Tarihi: 30.12.2020).

Topçu, E. (2020), RKI: Aşı bulunsa da maske, hijyen ve sosyal mesafe sürecek. https://www.dw.com/tr/rki-aş1-bulunsa-da-maske-hijyenve-sosyal-mesafe-sürecek/a-55263787. (Erişim Tarihi: 29.12.2020).

UNESCO, UNICEF and the World Bank (2020), What have we learnt? Overview of findings from a survey of ministries of education on national responses to COVID-19, Paris, New York, Washington D.C.: UNESCO, UNICEF, World Bank. http://tcg.uis.unesco.org/survey-education-covid-school-closures/ (Erişim Tarihi: 15.10.2020).

UNESCO Institute for Statistics (UIS), based on UNESCO-UNICEFWorld Bank (2020), Survey on National Education. Responses to COVID-19 School Closures, 1st Iteration. http://tcg.uis.unesco.org/survey-education-covid-school-closures. (Erişim Tarihi: 15.10.2020).

UNESCO, UNICEF and the World Bank (2020), Survey on National Education Responses to COVID-19 School Closures, round 2. Paris, New York, Washington D.C.: UNESCO, UNICEF, World Bank. (Erişim Tarihi: 15.10.2020). 
Vigdor, J.L. \& Ladd, H. F. (2010), Scaling the digital divide: Home computer technology and student achievement, Natıonal Bureau Of Economic Research. Paper No. 16078. https://doi.org/10.3386/w16078.

Yükseköğretim Kurulu.(2020), Küresel Salgın Bă̆lamında Yükseköğretim Kurumlarında Sağlıklı ve Temiz Ortamların Geliştirilmesi Klavuzu, https://www.yok.gov.tr/Sayfalar/Haberler/2020/yuksekogretimkurumlarinda-saglikli-ve-temiz-ortamlarin-gelistirilmesi-kilavuzuyayimlandi.aspx, (15.11.2020).

Yükseköğretim Kurulu.(2020), https://istatistik.yok.gov.tr/ (Erişim Tarihi: 29.11.2020)

YÖKAK (2020), Yükseköğretimde uzaktan eğitim ve kalite güvencesi sistemi. https://portal.yokak.gov.tr/makale/pandemi-donemindeuzaktan-egitim/. (Erişim Tarihi: 29.11.2020)

World Health Organization. (2020), Advice on the use of masks in the context of COVID-19: Interim guidance WHO reference number: Who/2019-Ncov/Ipc_Masks/2020.4 (Erişim Tarihi: 10.12.2020).

World Health Organization. (2020), Hand Hygiene: Why, How \& When, https://www.who.int/gpsc/5may/Hand_Hygiene_Why_Ho w_and_When_Brochure.pdf, (Erişim Tarihi: 12.12.2020).

World Health Organization. (2020), Rational use of personal protective equipment for coronavirus disease (COVID-19): interim guidance 19 March 2020. Who Reference Number: Who/2019-Ncov/Ipc Ppe_Use/2020.2, (Erişim Tarihi: 09.12.2020).

World Health Organization. (2020), Survey Tool And Guldance Rapid, simple, flexible behavioural insights on COVID-19, Document number: Who/Euro:2020-696-40431-54222, (Erişim Tarihi: 09.09.2020).

World Health Organization. (2020), Coronavirus disease 2019 (COVID19) Situation Report-51. https://www.who.int/docs/defaultsource/coronaviruse/situation-reports/20200311-sitrep-51-covid19.pdf?sfvrsn=1ba62e57_10, (Erişim Tarihi: 15.10.2020).

World Health Organization. (2020a), Q\&A on coronaviruses (COVID-19). https://www.who.int/emergencies/diseases/novel-coronavirus2019, (Erişim Tarihi: 09.10.2020).

World Health Organization. (2020), Who announces COVID-19 outbreak a pandemic. http://www.euro.who.int/en/health-topics/health- 
emergencies/coronavirus-covid-19/news/news/2020/3/whoannounces-covid-19-outbreak-a-pandemic, (Erişim Tarihi: 05.12.2020).

World Health Organization. (2020), Coronavirus disease (COVID-19) training: online training, https://www.who.int/emergencies/diseases/novel-coronavirus2019/training/online-training,_(Erişim Tarihi: 03.12.2020)

Xie, K., Liang, B., Dulebenets, M.A., Mei, Y. (2020), The Impact of Risk Perception on Social Distancing during the COVID-19 Pandemic in China. International Journal Environ Research and Public Health. 17(17), 6256. https://doi.org/10.3390/ijerph17176256.

Ek :

\begin{tabular}{|c|c|c|c|c|c|c|}
\hline & $\begin{array}{l}\text { COVID-19 FARKINDALIK ÖLÇEĞİ MASKE } \\
\text { MESAFE HİJYEN }\end{array}$ & 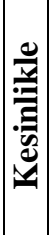 & 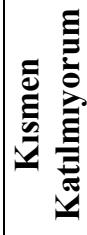 & 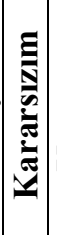 & 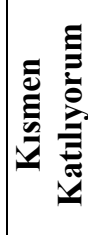 & 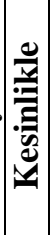 \\
\hline \multicolumn{7}{|c|}{ HIJYEN } \\
\hline 1 & $\begin{array}{l}\text { Kişisel yaşamımda hijyene (günlük duş, el hijyeni, diş } \\
\text { fırçalamak, elbisenin temizliği, ev temizliği vb.) dikkat } \\
\text { ederim. }\end{array}$ & 1 & 2 & 3 & 4 & 5 \\
\hline 2 & Ellerimi, yemeklerden önce/sonra yıkarım. & 1 & 2 & 3 & 4 & 5 \\
\hline 3 & Ellerimi, eve döndükten sonra yıkarım. & 1 & 2 & 3 & 4 & 5 \\
\hline 4 & $\begin{array}{l}\text { Ellerimi, toplu taşımayı kullandıktan sonra } \\
\text { yıkarım/dezenfekte ederim. }\end{array}$ & 1 & 2 & 3 & 4 & 5 \\
\hline 5 & $\begin{array}{l}\text { Ellerimi, para/banka kartı kullanımı sonrası } \\
\text { yıkarım/dezenfekte ederim. }\end{array}$ & 1 & 2 & 3 & 4 & 5 \\
\hline 6 & $\begin{array}{l}\text { Ellerimi, insanlarla temasa geçtikten sonra } \\
\text { yıkarım/dezenfekte ederim. }\end{array}$ & 1 & 2 & 3 & 4 & 5 \\
\hline 7 & $\begin{array}{l}\text { Ellerimi, burun sildikten, hapşırdıktan, öksürdükten } \\
\text { sonra yıkarım. }\end{array}$ & 1 & 2 & 3 & 4 & 5 \\
\hline 8 & $\begin{array}{l}\text { Ellerimi, çöplere dokunduktan sonra } \\
\text { yıkarım/dezenfekte ederim. }\end{array}$ & 1 & 2 & 3 & 4 & 5 \\
\hline 9 & Ellerimi yıkarken sabun kullanırım. & 1 & 2 & 3 & 4 & 5 \\
\hline 10 & $\begin{array}{l}\text { El hijyeni için tercih edilen en etkin yöntem, yaklaşık } \\
20 \text { saniye elleri sabunla iyice yıkamaktır. }\end{array}$ & 1 & 2 & 3 & 4 & 5 \\
\hline 11 & $\begin{array}{l}\text { Dışarı çıktığımda/ bulunduğum ortamdaki yüzeylerin } \\
\text { (masalar, sıralar) ve nesneler (telefonlar, klavyeler) } \\
\text { dezenfekte edilmiş olmasına dikkat ederim. }\end{array}$ & 1 & 2 & 3 & 4 & 5 \\
\hline 12 & $\begin{array}{l}\text { Ellerimi göz, ağız, burun gibi organlardan uzak } \\
\text { tutmaya dikkat ederim. }\end{array}$ & 1 & 2 & 3 & 4 & 5 \\
\hline
\end{tabular}




\section{MESAFE}

13 İki kişi arasındaki fiziksel mesafeye dikkat ederim. 14 Öksüren veya hapşıran herkesten en az 2 m uzakta durmaya dikkat ederim.

15 Toplu faaliyet düzenlenen (kafe, restoran, düğün vb.) alanlarda $2 \mathrm{~m}$ fiziksel mesafeye dikkat ederim.

16 Kapalı alanlarda (AVM, okul, vb.) kalabalık yerlerde 16 insanlarla fiziksel mesafeye dikkat ederim.

17 Birlikte yaşamadığım kişilerle (arkadaşlarım vd.) fiziksel mesafeye/yakın temasa dikkat ederim.

18 Toplu taşıma kullanırsam fiziksel mesafeye dikkat ederim.

\section{MASKE}

19 Koronavirüsün bulaşmasını önlemek için insanlar maske takmalıdır.

20 Maske kullanmayanlara cezai işlem uygulanmalı ve zorunlu olmalidır.

21 Maske takmanın koronavirüs yayılımının azaltılmasına yardımcı olduğunu düşünüyorum.

\begin{tabular}{|l|l|l|l|l|l|}
\hline & 1 & 2 & 3 & 4 & 5 \\
\hline b.) & 1 & 2 & 3 & 4 & 5 \\
\hline & 1 & 2 & 3 & 4 & 5 \\
\hline & 1 & 2 & 3 & 4 & 5 \\
\hline
\end{tabular}

\begin{tabular}{|l|l|l|l|l|l|} 
& 1 & 2 & 3 & 4 & 5 \\
\hline asina & 1 & 2 & 3 & 4 & 5 \\
\hline
\end{tabular}

